\title{
Self-Efficacy and Problem-Solving among College Students during COVID-19 Pandemic
}

\author{
Fatmawati $^{1 \bowtie}$, Siti Maryam ${ }^{2}$ \\ ${ }^{1}$ Faculty of Psychology, UIN Ar-Raniry Banda Aceh, Indonesia \\ ${ }^{2}$ Faculty of Education, Universitas Syiah Kuala Banda Aceh, Indonesia \\ 1fatmawati@ar-raniry.ac.id, 2sitimaryam@unsyiah.ac.id
}

\begin{abstract}
During the COVID-19 pandemic and the implementation of online learning system, the pressure faced by students is far greater than before. The existence of the problems certainly requires students to be able to survive and find the right way out. Problem-solving is an indication that shows how strong a person is in facing a difficulty. Students with high self-efficacy believe that they are able to do something to change the problems around them. Therefore, this study aimed to measure the association between self-efficacy and problem-solving among college students during COVID-19 pandemic. The number of participant recruited through accidental random technique was 150 college students in the city of Banda Aceh. General SelfEfficacy Scale was employed in order to obtain the data on self-efficacy, whereas problem-solving ability was calculated through Solving Problem Survey. Pearson Correlation was used to analyze the data and it showed a positive relationship between those two variables. Besides, the analysis also displayed a significance value of $0.000(\mathrm{p}<0.05)$. This indicated that the hypothesis was accepted -there was a very significant relationship between self-efficacy and problem-solving among college students during COVID-19 pandemic.
\end{abstract}

Keywords: Self-efficacy, Problem-solving, College student, COVID-19, Learning system.

\begin{abstract}
Abstrak
Di masa pandemi COVID-19 dan penerapan sistem pembelajaran online, tekanan yang dihadapi mahasiswa jauh lebih besar dari sebelumnya. Adanya permasalahan tersebut tentunya menuntut siswa untuk dapat bertahan dan menemukan jalan keluar yang tepat. Pemecahan masalah merupakan indikasi yang menunjukkan seberapa kuat seseorang dalam menghadapi suatu kesulitan. Siswa dengan efikasi diri yang tinggi percaya bahwa mereka mampu melakukan sesuatu untuk mengubah masalah yang ada di sekitarnya. Oleh karena itu, penelitian ini bertujuan untuk mengukur hubungan antara efikasi diri dan pemecahan masalah di kalangan mahasiswa selama pandemi COVID-19. Jumlah peserta yang direkrut melalui teknik accidental random sebanyak 150 mahasiswa di kota Banda Aceh. Skala Self-Efficacy Umum digunakan untuk mendapatkan data tentang selfefficacy, sedangkan kemampuan pemecahan masalah dihitung melalui Solving Problem Survey. Korelasi Pearson digunakan untuk menganalisis data dan menunjukkan hubungan positif antara kedua variabel tersebut. Selain itu, analisis juga menunjukkan nilai signifikansi sebesar 0,000 $(\mathrm{p}<0,05)$. Hal ini menunjukkan bahwa hipotesis diterima - terdapat hubungan yang sangat signifikan antara efikasi diri dengan pemecahan masalah mahasiswa pada masa pandemi COVID-19.
\end{abstract}

Kata kunci: Efikasi Diri, Pemecahan masalah, Mahasiswa, COVID-19, Sistem pembelajaran.

(ㄷ) 2021 PSY165 Journal

\section{Introduction}

During the COVID-19 pandemic and the implementation of online learning system, the pressure faced by students is far greater than before. Livana, Mubin, and Basthomi (2020) mention that there are a number of factors that cause high levels of student stress during the COVID-19 pandemic [1], including increased learning tasks, boredom at home, ineffective online learning processes, and not being able to participate optimally in online learning due to signal limitations.

The existence of these problems certainly requires students to be able to survive and find the right way out. Problem-solving is an indication that shows how strong a person is in facing a difficulty [2]. This is supported by Reed (2011) who states that problemsolving is an individual's way of finding solutions to the difficulties encountered in life in order to achieve the desired goals [3]. For this reason, problem-solving ability is very dependent on the individual's assessment of his abilities which is called as self-efficacy.

Self-efficacy plays a very important role in everyday life, a person is able to use his potential optimally if it is supported by good self-efficacy. According to Bandura (1999), self-efficacy is a person's belief to control over himself and environment [4]. AlemanyArrebola, Rojas-Ruiz, Granda-Vera, \& MingoranceEstrada (2020) say that self-efficacy is needed by students because it can lead to the choice of action, exertion of effort [5], and individual tenacity. Beliefs 
based on perceived limitations of ability require people efficacy and problem solving, the General Self-Efficacy to behave steadily and effectively.

Scale and Solving Problem Survey were used. General

Gist and Mitchell (in Ghufron, 2012) say that selfefficacy can lead to different behavior among individuals with the same ability because self-efficacy affects choices and goals [6]. Students with high selfefficacy believe that they are able to do something to change the problems around them [7]. In difficult situations, people with low self-efficacy tend to give up easily. Meanwhile, people with high self-efficacy will try harder to overcome the existing challenges [8]. Therefore, based on those explanations above, this current study aimed to measure the association between self-efficacy and problem-solving among college students during the COVID-19 pandemic.

\subsection{Problem-Solving}

Chaplin (2011) defines problem-solving as the process involved in finding the right sequence of alternative answers, leading to a single goal, or towards an ideal solution [9]. Meanwhile, Reber and Emily (2010) mention that problem-solving is a process involved in solving a problem [10]. Reed (2011) argues that problem-solving is looking for solutions to the difficulties faced in life to reduce ambiguity in achieving goals that sometimes cannot be understood by every individual. According to Ruch [11], there are Self-Efficacy Scale was developed by Schwarzer and Jerussalem (2010) with 18 items and has been tested with a high reliability of 0.787 [13], while Solving Problem Survey which was developed by Barkman and Machtmes (2002) has 36 items, this scale also showed a good reliability result with Cronbach Alpha of 0.879 [14]. The data was collected through Google Form, then it was tabulated and analyzed by the Pearson Correlation. SPSS version 20.0 for Windows was operated to simplify all the statistical calculation processes within this study

\section{Results and Discussions}

\subsection{Description of Participants}

Table 1 below will show the demographic data of participants in this study.

Table 1. Demographic Data of Participants

\begin{tabular}{lllcc}
\hline No & Description & \multicolumn{1}{c}{ Category } & $\begin{array}{c}\text { Total } \\
(\mathrm{n})\end{array}$ & $\begin{array}{c}\text { Percentage } \\
(\%)\end{array}$ \\
\hline 1. & Sex & Female & 89 & 59.33 \\
& & Male & 61 & 40.67 \\
\hline 2. & University & Universitas Syiah & 78 & 52.00 \\
& & Kuala & 72 & 48.00 \\
& & UIN Ar-Raniry & & \\
\hline
\end{tabular}
several stages of problem-solving, included: (a) From table 1 shown above, it clearly mentioned that drawing the attention to the problem; (b) collecting female respondents $(n=89 ; 59.33 \%)$, were more valuable sources that can be used as information to dominant than male respondents $(\mathrm{n}=61 ; 40.67 \%$ ). solve a problem; (c) selecting the possible solutions; Based on university, the majority respondents were and (4) implement solutions objectively.

\subsection{Self-Efficacy}

Bandura (1999) says that self-efficacy is basically the result of cognitive processes in the form of decisions, Categorization of the participants was sorted based on beliefs, or expectations about the extent to which the size of population standard deviation unit [15]. individuals estimate their abilities to carry out certain Because this categorization is relative, the extent of tasks or actions to achieve the desired results. Someone interval covering each desired category can be with high self-efficacy believes that they are able to do subjectively revealed as long as the determination is something to change the existing problems, while within the reasonable limits. Hence, based on this someone with low self-efficacy considers himself technique, the categorization of participants for selfbasically unable to solve everything that happens to efficacy and problem-solving was divided into two him. In difficult situations, people with low self- categories, namely low and high. The following is the efficacy will tend to give up easily. Meanwhile, people description of participants based on these with high self-efficacy will try harder to overcome the categorization. existing challenges. The same thing was said by PérezFuentes et al. (2019), who showed evidence that selfefficacy plays an important role in motivating workers The following is the description of participants based to complete challenging jobs in relation to the on self-efficacy categorization in Table 2 . achievement of certain goals [12].

\section{Methods}

This study utilized a quantitative research design. The number of participants recruited through accidental random sampling technique was 150 college students in the city of Banda Aceh. In order to measure self- 
Table 2. Data Description on self-efficacy

\begin{tabular}{lcccccccc}
\hline \multirow{2}{*}{ Variable } & \multicolumn{4}{c}{ Hypothetical Data } & \multicolumn{4}{c}{ Empirical Data } \\
\cline { 2 - 9 } & X-max & X-min & Mean & SD & X-max & X-min & Mean & SD \\
\hline Self-Efficacy & 72 & 18 & 45 & 9 & 70 & 35 & 55.19 & 6.54 \\
\hline
\end{tabular}

Based on statistical analysis, hypothetical descriptive Efficacy Scale which consists of 18 items had data showed that General Self-Efficacy Scale which minimum score (X-min) of 35, maximum score (Xconsists of 18 items had minimum score (X-min) of 18, max) of 70, mean value (M) of 55.19, and standard maximum score (X-max) of 72, mean value (M) of 45, deviation (SD) of 6.54. After the results of empirical and standard deviation (SD) of 9. Furthermore, analysis were obtained, the mean value (M) and empirically, the results of analysis through SPSS standard deviation (SD) can be used to attain the version 20.0 for Windows obtained that General Self- categories for each variable, in Table 3.

Table 3. Participants' Self-Efficacy Categorization

\begin{tabular}{ccccc}
\hline Category & Categorization Formula & Interval & Frequency $(\mathrm{n})$ & Percentage (\%) \\
\hline Low & $\mathrm{X}<\mathrm{M}-1,0 \mathrm{SD}$ & $\mathrm{X}<48.65$ & 48 & 32.00 \\
High & $\mathrm{X} \geq \mathrm{M}-1,0 \mathrm{SD}$ & $\mathrm{X} \geq 48.65$ & 102 & 68.00 \\
\hline \multicolumn{5}{c}{ b. Problem-Solving }
\end{tabular}

Based on the table above, it can be seen that as many as The following is the description of participants based $32 \%(n=48)$ had low self-efficacy and 68\% $(n=102)$ on problem-solving categorization in Table 4. had high self-efficacy.

Table 4. Data Description on problem-solving

\begin{tabular}{ccccccccc}
\hline \multirow{2}{*}{ Variable } & \multicolumn{4}{c}{ Hypothetical Data } & \multicolumn{4}{c}{ Empirical Data } \\
\cline { 2 - 9 } & X-max & X-min & Mean & SD & X-max & X-min & Mean & SD \\
\hline Problem-Solving & 144 & 36 & 90 & 18 & 139 & 79 & 113.05 & 11.70 \\
\hline
\end{tabular}

Based on the table above, it can be seen that as many as b. Linearity Testing $36 \%(n=54)$ had low problem-solving ability and $64 \%$ $(n=96)$ had high problem-solving ability.

The results of linearity testing were described in Table 6.

\subsection{Prerequisite Testing}

Table 6. Linearity Testing Results

Before analyzing the data through Pearson Correlation, the initial analysis that required to fulfill is prerequisite testing [16]. The prerequisite testing conducted in this study were normality testing and linearity testing.

\section{a. Normality Testing}

The results of normality testing were described in Table 5.

Table 5. Normality Test Results

\begin{tabular}{cccc}
\hline No. & Variable & K-S Z Coefficient & $p$ \\
\hline 1. & Self-Efficacy & 0.998 & 0.272 \\
2. & Problem-Solving & 0.568 & 0.904 \\
\hline
\end{tabular}

Based on table 5 above, it was found that data for selfefficacy was normally distributed with K-S Z coefficient of $0.998(\mathrm{p}=0.272 ; \mathrm{p}>0.05)$. While data distribution on problem-solving was also normally distributed with K-S Z coefficient of 0.568 ( $p=904$; $\mathrm{p}>0.05)$. As both variables were normally distributed, the results of this study could be generalized into the whole population.

\begin{tabular}{ccc}
\hline Variable & $\begin{array}{c}\text { F Deviation from } \\
\text { Linearity }\end{array}$ & $p$ \\
\hline $\begin{array}{c}\text { Self-Efficacy and Problem- } \\
\text { Solving }\end{array}$ & 1.270 & 0.191 \\
\hline
\end{tabular}

Table 6 above presented $\mathrm{F}$ deviation from linearity of the two variables was $1.270(p=0.191 ; p>0.05)$, thus, it can be concluded that there was a linear relationship self-efficacy and problem-solving among college students during COVID-19 pandemic.

\subsection{Hypothesis Testing}

The hypothesis testing was completed by using Pearson Correlation, this analysis could be performed because both variables were normally distributed and linear (as clearly described above). Pearson Correlation was employed to analyze the relationship between selfefficacy and problem-solving among college students during COVID-19 pandemic. 
Table 7. Hypothesis Testing Results

\begin{tabular}{ccc}
\hline Variable & Pearson Correlation & $p$ \\
\hline Self-Efficacy and Problem-Solving & 0.670 & 0.000 \\
\hline
\end{tabular}

Table 7 showed that the correlation coefficient was 0.670 which was a positive correlation. This presented that there was a positive relationship between selfefficacy and problem-solving. This positive correlation also revealed that the higher the self-efficacy, the better the problem solving ability of college students, and vice versa. Moreover, the results from of the analysis displayed a significance value of $0.000(\mathrm{p}<0.05)$. This indicated that the hypothesis was accepted -there was a very significant relationship between self-efficacy and problem-solving among college students during COVID-19 pandemic.

The results showed that the majority of college students in the city of Banda Aceh had a high self-efficacy category. Other findings also mentioned that most of them were categorized as having a high problemsolving ability. In addition, based on the Pearson Correlation results, it was obtained that there was a positive and significant relationship between selfefficacy and problem-solving. This implied that the higher the self-esteem, the better problem-solving ability, and vice versa. This finding confirms that a high self-efficacy may impact someone ability in solving problem effectively.

The findings from this research were relevant with several previous studies. In general, self-efficacy is a person's assessment of his own ability to carry out certain behaviors or achieve certain goals (Bandura, 1999). People are more likely to engage in certain behaviors when they believe that they are capable of performing the behavior successfully, this shows that they have high self-efficacy. Researchers have found that self-efficacy can improve academic achievement if students set specific and challenging short-term goals [17]. Therefore, in order to achieve a goal, high selfefficacy is needed.

Gist and Mitchell (in Ghufron, 2010) say that selfefficacy can lead to different behavior among individuals with the same ability because self-efficacy affects choices [6], goals, problem-solving, and persistence in trying. High self-efficacy reduces fear of failure, increases aspirations, and improves problemsolving as well as analytical thinking skills [18]. In overcoming problems arising from online learning system during the COVID-19 pandemic, college students are expected to have high self-efficacy so that the problems experienced can be handled properly and do not interfere with academic achievement. Bandura (1999) reveals that self-efficacy plays a central role in the emergence of anxiety, so it stimulates the rise of high self-efficacy which aims to reduce intrusive aversive thoughts related to the problems faced.
Although this research contributed to some advantages, it also had some limitations. First, the subjective measures used were only General Self-Efficacy Scale and Solving Problem Survey, thus, other psychological aspects affected the ability of solving problem could not be traced. Besides, as the participants only college students, so the results could not be generalized into other population types, including school-aged children or adolescents. Not only that, as the correlation was only utilized to measure the association, the findings were less comprehensive.

\section{Conclusion}

From this study, it was found that the majority of college students in Banda Aceh city were included into high self-efficacy category $(\mathrm{n}=102 ; 68.0 \%)$. For problem-solving, most of the college students also had high problem-solving ability with a percentage of $64.0 \% \quad(n=96)$. Furthermore, based on the result obtained from Pearson Correlation analysis, it was found that there was a positive relationship between self-efficacy and problem-solving with r-count of 0.670 and a significance of $0.000(\mathrm{p}<0.05)$. These results inferred that the hypothesis was accepted, which meant the higher the self-efficacy, the better the problemsolving ability, and vice versa.

The findings from this study give significant contribution to the important of self-efficacy on problem-solving ability. However, based on the limitations mentioned above, there are some points highlighted as the recommendations for further research. First, in order to enrich the results and analyses, the addition of other variables needs to be considered. In addition, future research might also increase the number of respondents, thus the validity and reliability of research results will be improved. Lastly, the using of statistical analysis can be expanded, so the results obtained will be more comprehensive.

\section{Daftar Rujukan}

[1] Livana, P. H., Mubin, M. F., \& Basthomi, Y. (2020). "Learning Task" Attributable to Students' Stress during the Pandemic Covid-19. Jurnal Ilmu Keperawatan Jiwa, 3(2), 203-208.

2] Aydoğdu, M. Z., \& Keşan, C. (2014). A research on geometry problem solving strategies used by elementary mathematics teacher candidates. Engineering Sciences \& Technologies/Nauki Inzynierskie i Technologie, 4(1).

[3] Reed, S, K. (2011). Kognisi: Teori dan Aplikasi. Jakarta: Salemba Humanika.

[4] Bandura, A. (1999). Self-Efficacy the Exercise of Control. W.H. Freeman And Company.

[5] Alemany-Arrebola, I., Rojas-Ruiz, G., Granda-Vera, J., \& Mingorance-Estrada, Á. C. (2020). Influence of COVID-19 on the perception of academic self-efficacy, state anxiety, and trait anxiety in college students. Frontiers in Psychology, 11, 1-7.

[6] Ghufron, M. N. (2012). Teori-Teori Psikologi. Yogyakarta: ArRuzz Media.

[7] Aguilera-Hermida, A. P. (2020). College students' use and acceptance of emergency online learning due to Covid19. International Journal of Educational Research Open, 1, 100011. 
[8] Bradley, R. L., Browne, B. L., \& Kelley, H. M. (2017). Examining the influence of self-efficacy and self-regulation in online learning. College Student Journal, 51(4), 518-530.

[9] Chaplin. J.P. (2011). Kamus Lengkap Psikologi. Jakarta: Raja [15] Grafindo Persada.

[10] Reber, A.S. \& Emily, S. R. (2010). Kamus Psikologi. Yogyakarta: Pustaka Pelajar.

[11] Arifin, M. (1994). Ilmu Perbandingan Pendidikan. Jakarta: PT. Golden Terayon Press.

[12] Pérez-Fuentes, M. D. C., Molero Jurado, M. D. M., Barragán Martín, A. B., Simón Márquez, M. D. M., Martos Martínez, Á., \& Gázquez Linares, J. J. (2019). The mediating role of perceived stress in the relationship of self-efficacy and work engagement in nurses. Journal of Clinical Medicine, 8(1), 10.

[13] Schwarzer, R., \& Jerusalem, M. (2010). The general selfefficacy scale (GSE). Anxiety, Stress, and Coping, 12(1), 329345 .
[14] Barkman, S. \& Machtmes, K. (2002) Four-fold: A research model for designing and evaluating the impact of youth development programs. News and Views, 4, 4-6.

5] Azwar, S. (2015). Metode Penelitian. Yogyakarta: Pustaka Belajar.

16] Priyatno, D. (2011). Buku Saku Analisis Statistik Data SPSS. Yogyakarta: Media Kom

[17] Affuso, G., Bacchini, D., \& Miranda, M. C. (2017). The contribution of school-related parental monitoring, selfdetermination, and self-efficacy to academic achievement. The Journal of Educational Research, 110(5), 565-574.

[18] Grøtan, K., Sund, E. R., \& Bjerkeset, O. (2019). Mental health, academic self-efficacy and study progress among college students-The SHoT study, Norway. Frontiers in psychology, 10, 45 . 